Research article

\title{
Heavy metal exposure reverses genetic resistance to Chlamydia-induced arthritis
}

Robert D Inman ${ }^{1,2}$ and Basil Chiu'1,2

\author{
1Division of Genes and Development, Toronto Western Research Institute, 399 Bathurst Street, Toronto, ON, M5T 2S8, Canada \\ 2Department of Medicine, University of Toronto, 190 Elizabeth Street, Toronto, ON, M5G 2C4, Canada \\ Corresponding author: Robert D Inman, robert.inman@uhn.on.ca
}

Received: 9 Aug 2008 Revisions requested: 10 Sep 2008 Revisions received: 19 Dec 2008 Accepted: 9 Feb 2009 Published: 9 Feb 2009

Arthritis Research \& Therapy 2009, 11:R19 (doi:10.1186/ar2610)

This article is online at: http://arthritis-research.com/content/11/1/R19

(C) 2009 Inman and Chiu; licensee BioMed Central Ltd.

This is an open access article distributed under the terms of the Creative Commons Attribution License (http://creativecommons.org/licenses/by/2.0), which permits unrestricted use, distribution, and reproduction in any medium, provided the original work is properly cited.

\begin{abstract}
Introduction We have previously observed that Brown Norway (BN) rats display a relative resistance to experimental Chlamydia-induced arthritis. In the present study, we examine an environmental toxin, mercuric chloride $\left(\mathrm{HgCl}_{2}\right)$, as a modulator of this innate resistance to arthritis.
\end{abstract}

Methods To assess the effect of the heavy metal exposure, one group of rats received two subcutaneous injections of $\mathrm{HgCl}_{2}$ (1 $\mathrm{mg} / \mathrm{kg}$ ) 48 hours apart. Seven days later, the animals received the intra-articular injection of synoviocyte-packaged Chlamydia.

Results Histopathology revealed that $\mathrm{BN}$ rats receiving only Chlamydia had a minimal cellular infiltration in the joint, which was predominantly mononuclear in character. In contrast, mercury-exposed rats had a marked exacerbation of the histopathological severity of the arthritis, and the infiltration was predominantly neutrophilic. Mercury exposure was also associated with marked enhancement in $\lg E$ levels and an alteration in IgG2a/lgG1 ratio, reflecting a Th2 shift. The local cytokine profile in the joint was markedly altered after mercury exposure, with a suppression of tumour necrosis factor-alpha and interferon-gamma but an enhancement of vascular endothelial growth factor. This was associated with decreased host clearance capacity reflected in enhanced bacterial load in both the spleen and the joint and was accompanied by enhanced detection of microbial antigens in the synovial tissues by immunohistological staining.

Conclusions Genetically defined cytokine production in the joint defines the severity of reactive arthritis by dictating the local clearance of the pathogen. This interplay can be altered dramatically by heavy metal exposure, which results in suppression of protective cytokines in the microenvironment of the joint.

\section{Introduction}

Many rheumatic diseases are thought to reflect an interplay of genetic susceptibility and environmental triggers, but there are few examples in which strong clues for the nature of these interacting elements are known. One such example is reactive arthritis ( $\operatorname{ReA})$, in which susceptible individuals develop an aseptic arthritis following an extra-articular infection. Yet dissecting the immune mechanisms in ReA has proven to be difficult in the clinical setting. Experimental Chlamydia trachomatis-induced arthritis (CtIA) affords the opportunity to systematically address the factors that define outcomes after exposure to this arthritogenic pathogen [1]. We have recently observed that the Brown Norway (BN) rat is resistant to CtIA
[2], with minimal transient inflammation in the joint. The infiltrating cell population in the joint is primarily mononuclear in nature and joint damage is minimal. This contrasts with an aggressive neutrophilic infiltration with associated joint injury that is seen in susceptible strains.

In contrast to their inherent resistance to this arthritis, BN rats are uniquely susceptible to the development of a variety of autoimmune conditions mediated mainly through Th2 mechanisms [3]. One such condition is the development of autoimmunity subsequent to an exposure of mercury [4]. The hallmarks of this condition are the increase of circulating $\lg \mathrm{E}$, the overproduction of interleukin-4 (IL-4), and the activation of

BN: Brown Norway; CFU: colony-forming units; CRP: C-reactive protein; Ct: Chlamydia trachomatis; CtIA: Chlamydia trachomatis-induced arthritis; ELISA: enzyme-linked immunosorbent assay; $\mathrm{Hg}$ : mercury; $\mathrm{HgCl}_{2}$ : mercuric chloride; hsp60: heat shock protein 60; IFN- $\gamma$ : interferon-gamma; IL: interleukin; NO: nitric oxide; PBS: phosphate-buffered saline; ReA: reactive arthritis; SF: synovial fibroblast; SpA: spondyloarthropathy; TNF- $\alpha$ : tumour necrosis factor-alpha; VEGF: vascular endothelial growth factor. 
Th2 cells $[5,6]$. The normal CD4/CD8 balance and their associated cytokines are markedly disrupted [7]. This is accompanied by the appearance of a range of autoantibodies $[5,8,9]$. Early pivotal studies examining the effects of mercuric chloride $\left(\mathrm{HgCl}_{2}\right)$ in rats documented a significant increase in total lgE and this was observed in $\mathrm{BN}$ rats but not in Lewis rats [10]. Subsequent studies revealed that $\mathrm{HgCl}_{2}$ induction of IL-4 was accompanied by a decrease in CD23 expression on B cells and that IL-2, IL-6, and IL-10 were upregulated as well as IL-4 following $\mathrm{HgCl}_{2}$ exposure in $\mathrm{BN}$ rats $[11,12]$. Because the $\mathrm{BN}$ rat displays a dichotomy of resistance to infection-triggered arthritis but susceptibility to mercury-induced immune disruption, we addressed how these factors would interact if they were temporally related in the rat.

\section{Materials and methods} Animals

Eight week-old male BN rats were purchased from Harlan Laboratories, Inc. (Indianapolis, IN, USA). The animals were maintained in microisolators under specific pathogen-free conditions in the animal care facility of the Toronto Western Hospital. All animals studied were less than 12 weeks of age. The studies were conducted with the approval of the Animal Care Committee of the University Health Network.

\section{Induction of arthritis}

Chlamydia trachomatis-induced arthritis

Arthritis was induced in the rats by intra-articular injection of synoviocyte-packaged Chlamydia as described [2]. Briefly, C. trachomatis serotype L2 was inoculated onto monolayers of rat synovial fibroblasts (SFs) in tissue culture. These stable SF lines were developed as described [1]. After overnight incubation, cells were harvested and adjusted to $5 \times 10 \mathrm{PP} 5 \mathrm{PP} / \mathrm{mL}$. Rats were anaesthetized with isoflurane (Pharmaceutical Partners of Canada, Richmond Hill, ON, Canada), and $0.2 \mathrm{~mL}$ of the infected cells containing $2 \times 10$ PP5PP colony-forming units (CFU) of Chlamydia was injected into the knee joint. Joint swelling was measured with a caliper and recorded in millimetres. Animals were euthanized at day 7 post-injection. Mock injections on non-infected synoviocytes had previously been shown to induce only a transient inflammation in the joint.

\section{Protocol and injection schedule for $\mathbf{H g C l}_{2}$}

Several different dose schedules have been used previously by investigators to address response to $\mathrm{HgCl}_{2}[5,6,8,9]$. Roos and colleagues $[13,14]$ used a two-injection abbreviated schedule to investigate the short-term effects of $\mathrm{HgCl}_{2}$ exposure. This protocol was associated with less morbidity than other protocols using five injections over a 10-day period. These investigators observed that distinctive immunological changes were rapid and were observed as early as 4 days after the initial $\mathrm{HgCl}_{2}$ exposure, with minimal toxicity. We therefore adopted the two-injection protocol of Roos and colleagues [13,14]. $\mathrm{HgCl}_{2}$ (Sigma-Aldrich, St. Louis, MO, USA) was dissolved in water at $1 \mathrm{mg} / \mathrm{mL}$ and then filter-sterilized.
The rats were anaesthetized by inhalation using isoflurane, weighed, and injected with the $\mathrm{HgCl}_{2}$ solution subcutaneously at a dosage of $1 \mathrm{mg} / \mathrm{kg}$ of body weight. Two days later, the injection procedure was repeated. The animals tolerated this procedure well, with no local or systemic adverse effects noted. There was no joint swelling or joint discomfort noted following the two injections of $\mathrm{HgCl}_{2}$. Seven days after the second $\mathrm{HgCl}_{2}$ injection, the rats were anaesthetized again and synoviocyte-packaged Chlamydia $\left(2 \times 10^{5} \mathrm{CFU}\right)$ was delivered by intra-articular injection into the knee joint in accordance with our established protocol [2]. Control rats without antecedent exposure to $\mathrm{HgCl}_{2}$ received a similar intra-articular injection of synviocyte-packaged Chlamydia. One week after the injection of the joint, the animals were sacrificed by anaesthetic overdose. Eight animals were used for each comparative experimental condition.

\section{Processing and pathology}

The knee joints were removed and fixed in formalin. The lateral width of each joint was measured with a caliper. After measurement, the joints were decalcified and processed for histopathological scoring as described [2]. Immunopathology studies used a primary antibody specific for C. trachomatis (AbD Serotec, Oxford, Oxfordshire, UK) that was developed with a peroxidase-conjugated anti-mouse antibody.

\section{Chlamydia quantitation}

The Dako IDEIA ${ }^{\text {TM }}$ PCE Chlamydia Kit (Dako, Ely, Cambridgeshire, UK) was used for determining the clearance of the pathogen. Seven days after the intra-articular injection of Chlamydia, the $\mathrm{HgCl}_{2}$-exposed and non-exposed rats were sacrificed. Spleens were removed and ground over a Falcon Cell Strainer (BD Biosciences 2280 Argentia Road, Mississauga, ON L5N 6H8, Canada) using the rubber end of a syringe in a Petri dish containing $10 \mathrm{~mL}$ of phosphate-buffered saline (PBS). The tissue homogenate suspensions were frozen at $-70^{\circ} \mathrm{C}$ until tested. For analysis of synovial tissue, the injected joints were dissected and the tissues were removed. Tissues were stored in $1 \mathrm{~mL}$ of the transport buffer provided with the enzyme-linked immunosorbent assay (ELISA) kit and then were frozen as above.

\section{Serology}

Blood was obtained from the rats at sacrifice by cardiac puncture. Sera were separated and frozen at $-70^{\circ} \mathrm{C}$ until used. Results reflect serological changes 14 days after $\mathrm{HgCl}_{2}$ exposure and 7 days after onset of CtIA.

\section{Total serum IgE}

Elevation in serum IgE is the hallmark of $\mathrm{Hg}$-induced autoimmunity in the BN rat. The ELISA for total serum IgE was performed using an antibody pair kit from $A b D$ Serotec in accordance with the protocol of the manufacturer. A mouse anti-rat lgE monoclonal antibody was used to coat the ELISA plate. All sera were diluted 1:100 and incubated in the wells 
for 90 minutes. This was followed by the second antibody, peroxidase-conjugated anti-rat kappa/lambda, which was used at a 1:2,000 dilution for a second 90-minute incubation. O-phenylenediamine (Sigma-Aldrich) was used for development, and the plates were read at $490 \mathrm{~nm}$.

\section{Anti-Chlamydia antibodies}

The anti-Chlamydia antibody ELISA followed our published methods [1]. ELISA plates were coated with a $10-\mu \mathrm{g} / \mathrm{mL}$ preparation of Chlamydia in a $\mathrm{pH} 9.6$ carbonate-bicarbonate buffer overnight at $4^{\circ} \mathrm{C}$. A single batch of plates was prepared and kept frozen. Rat sera were diluted 1:200 in PBS containing $1 \%$ bovine serum albumin (BSA) as blocking agent, and 0.2 $\mathrm{mL}$ was added to each well in triplicate. After 90 minutes of incubation at $37^{\circ} \mathrm{C}$, plates were washed and peroxidase-conjugated antibodies were added. Peroxidase-conjugated goat anti-rat lgG1 and lgG2a secondary antibodies were obtained from Bethyl Laboratories, Inc. (Montgomery, TX, USA) and used at a 1:10,000 dilution. After a further 90-minute incubation at $37^{\circ} \mathrm{C}$, the plates were washed and colour-developed with o-phenylenediamine $(0.4 \mathrm{mg} / \mathrm{mL})$ as substrate. Plates were read at $490 \mathrm{~nm}$ with an ELISA plate reader.

\section{Anti-collagen $_{(I I)}$ antibodies}

The ELISA kit for the rat anti-type II collagen antibodies was from Chondrex (Redmond, WA, USA) and followed the protocol of the manufacturer. Rat serum was run at a 1:200 dilution in the assay.

\section{Cytokines}

Serum and synovial tissue cytokine levels in the Hg-exposed and non-exposed $\mathrm{BN}$ rats were assayed as previously described [2]. Rat interferon-gamma (IFN- $\gamma$ ), tumour necrosis factor-alpha (TNF- $\alpha$ ), IL-4, and IL-10 were assayed by ELISA kits purchased from Pierce Endogen (Thermo Fisher Scientific Inc., Rockford, IL, USA). The ELISA for rat vascular endothelial growth factor (VEGF) was purchased from Bender MedSystems (Vienna, Austria).

\section{Nitric oxide}

The kit to determine total nitric oxide (NO) concentrations was from R\&D Systems (Minneapolis, MN, USA) (KGE001). This is a colorimetric assay using the Griess reaction with the entire procedure performed on an ELISA plate. The serum samples are filtered through 10,000-molecular weight cutoff spin filter units (Millipore Microcon YM-10; Millipore Corporation, Billerica, MA, USA) prior to the assay. Serum samples $(0.5 \mathrm{~mL}$ in size) were loaded on top of the filter units and then centrifuged in Eppendorf centrifuge at a speed of 14,000 rotations per minute for 30 minutes at room temperature.

\section{Statistical analysis}

The Student $t$ test was used to compare statistical differences between groups.

\section{Results Acute inflammatory response}

After induction of CtIA, a significant difference was observed between the $\mathrm{HgCl}_{2}$-exposed rats compared with controls. The rats with a prior exposure to $\mathrm{HgCl}_{2}$ demonstrated significantly more joint swelling compared with the normally mild swelling of naïve $\mathrm{BN}$ rats using the same injection protocol. The mean joint width in the $\mathrm{HgCl}_{2}$-exposed rats $(\mathrm{n}=8)$ was $13.7 \pm 0.53$ $\mathrm{mm}$ in comparison with a control joint mean size $(\mathrm{n}=8)$ of 9.6 $\pm 0.86 \mathrm{~mm}(P<0.0001)$ (Figure 1a).

Histologically, two systemic injections of $\mathrm{HgCl}_{2}$ induced no pathological changes in the joint (Figure 2). The CtIA in the non- $\mathrm{HgCl}_{2}$-exposed control rats was accompanied by only modest synovial hypertrophy and hyperplasia (Figure 2). Synovial tissue cellular infiltration was pleomorphic, with mononuclear cells comprising the dominant population. Pannus formation was minimal and there were only mild changes in

\section{Figure 1}

(a)

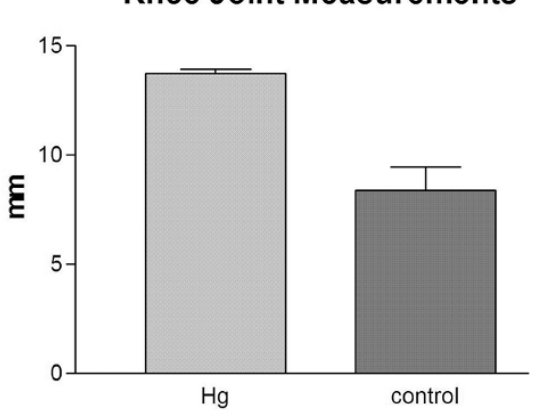

(b)

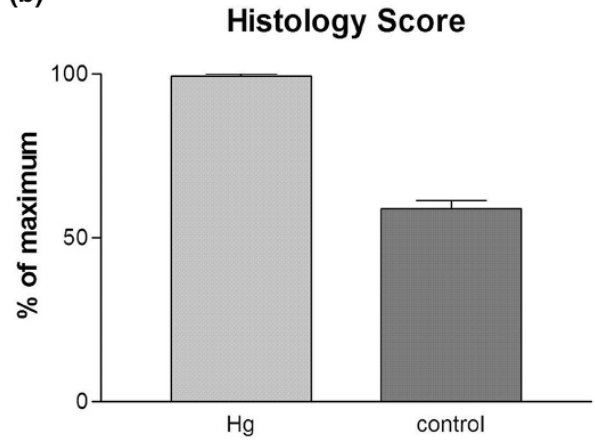

Joint swelling and histopathology scores demonstrating exacerbation of Chlamydia-induced arthritis following a prior systemic exposure to mercuric chloride $\left(\mathrm{HgCl}_{2}\right)\left(\mathrm{n}=8\right.$ in each group). The differences after $\mathrm{HgCl}_{2}$ exposure are significant $(P<0.005)$ in both joint swelling (a) and histopathological severity scores (b). $\mathrm{Hg}$, mercury. Ct, Chlamydia trachomatis. 
Figure 2
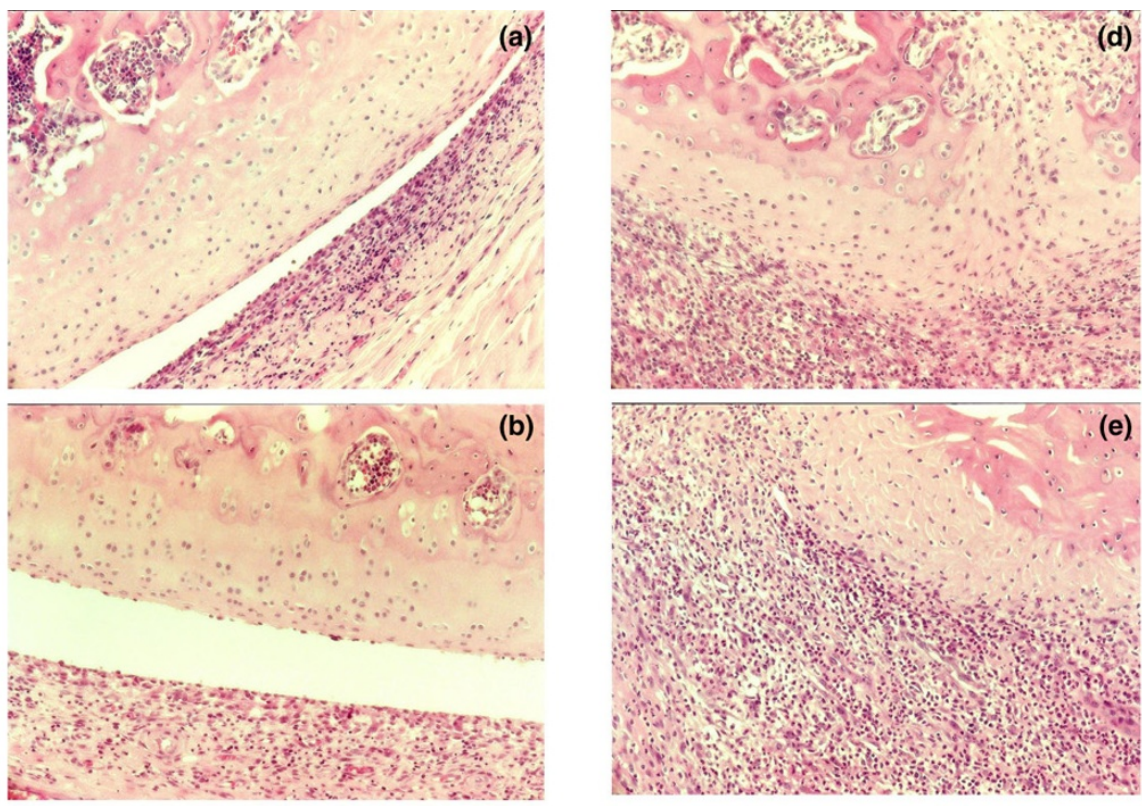

(b)
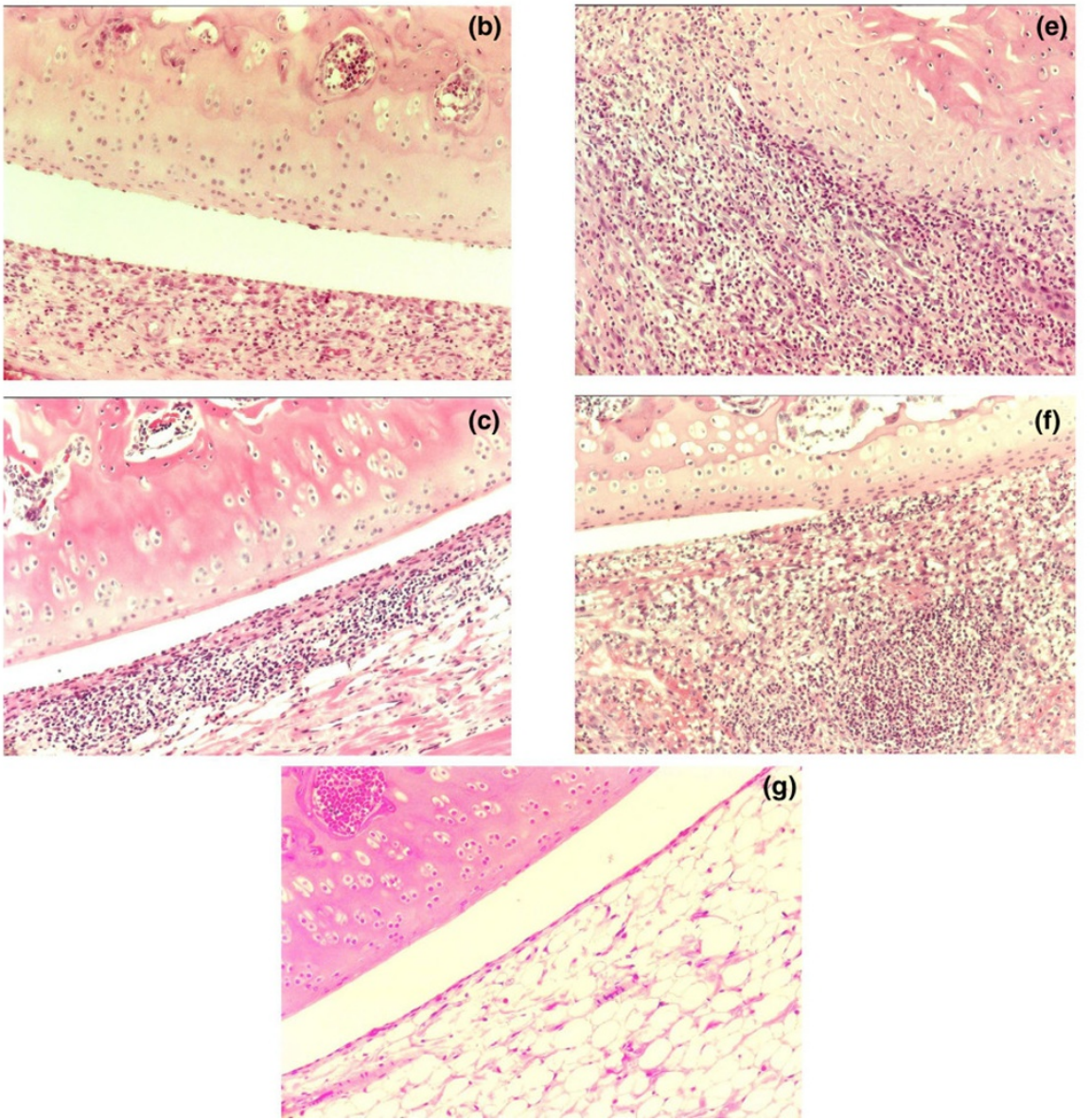

Histopathology (haematoxylin and eosin) in Chlamydia trachomatis-induced arthritis (CtIA) alone and after a prior exposure to mercuric chloride $\left(\mathrm{HgCl}_{2}\right)$. CtIA in the non- $\mathrm{HgCl}_{2}$-exposed control rats is accompanied by only moderate synovial hypertrophy and hyperplasia and a mononuclear cell infiltration (a-c). Eight animals were studied in each group. The joints of the $\mathrm{HgCl}_{2}$-exposed rats demonstrated more marked synovial hypertrophy and hyperplasia and a marked infiltration of the synovial tissues, primarily by neutrophils. This is accompanied by bone and cartilage destruction and by pannus formation, which invades subchondral bone $(\mathbf{d}-\mathbf{f})$. Panel $\mathbf{( g )}$ is representative of a rat that received the $\mathrm{HgCl}_{2}$ injections alone and shows no pathological change in the joint. Original magnifications $\times 200$.

bone and cartilage. This is the pattern observed in BN rats in our previous studies [2]. In contrast, the joints of the $\mathrm{HgCl}_{2}$ exposed rats demonstrated more marked synovial hypertrophy and hyperplasia (Figure 2). This was accompanied by massive infiltration of the synovial tissues with a predominance of neutrophils. There were areas of necrosis and bone and cartilage destruction by aggressive pannus formation. The invading pannus could be seen invading subchondral bone. Thus, the
$\mathrm{HgCl}_{2}$ exposure altered the mild arthritis characteristic of resistant $\mathrm{BN}$ into the aggressive profile of the arthritis characteristic of susceptible rats. When the histopathological scoring system was applied, the joint scores of the $\mathrm{HgCl}_{2}$-exposed test rats $(n=8)$ were significantly higher (average score of $99.28 \% \pm 1.89 \%$ of maximum) than those of controls (average score of $58.75 \% \pm 7.44 \%$ of maximum) $(P<0.0001)$ (Figure 1b). 


\section{Serum IgE}

There was a dramatic elevation of serum IgE levels (Figure 3) in $\mathrm{HgCl}_{2}$-exposed animals $(1.66 \pm 0.05)$ compared with controls $(0.30 \pm 0.07)$, representing a 4.5 -fold increase with $\mathrm{HgCl}_{2}$ exposure $(P<0.0001)(\mathrm{n}=8$ in each group).

\section{Anti-Chlamydia antibodies}

The $\mathrm{HgCl}_{2}$-exposed rats $(\mathrm{n}=8)$ had significantly higher serum IgG1 anti-Chlamydia antibodies $(0.26 \pm 0.05)$ than nonexposed control rats $(0.13 \pm 0.03)(P<0.001)$ (Figure $4 a$ ). On the other hand, the control rats $(n=8)$ had slightly higher $(P=0.12) \lg \mathrm{g} 2 \mathrm{a}$ anti-Chlamydia antibodies (0.21 \pm 0.02$)$ than the $\mathrm{HgCl}_{2}$-exposed rats $(0.18 \pm 0.03)$. The $\operatorname{lgG} 2 \mathrm{a}$ to IgG1 ratio was 1.57 for the control rats in contrast to 0.70 for the $\mathrm{HgCl}_{2}$-exposed animals, consistent with a shift toward a Th2 response after $\mathrm{HgCl}_{2}$ exposure.

\section{Anti-collagen $_{(I I)}$ antibodies}

The $\mathrm{HgCl}_{2}$-exposed $\mathrm{BN}$ rats $(\mathrm{n}=8)$ had higher levels of $\operatorname{lgG}$ antibodies to rat type II collagen than did controls: $0.108 \pm$ 0.069 versus $0.032 \pm 0.012(P<0.01)$. These serological changes paralleled the enhanced severity of arthritis clinically and histologically following $\mathrm{HgCl}_{2}$ exposure (Figure $4 \mathrm{~b}$ ).

\section{Cytokine profiles}

After intra-articular injection with Chlamydia, there was an increase in the serum levels of IFN- $\gamma(n=4)$ and TNF- $\alpha(n=4)$ (Figure 5a). These were significant increases compared with normal rat serum for both IFN- $\gamma(P<0.005)$ and TNF- $\alpha(P<$ $0.001)$. There were no significant increases in serum IL-10 or IL-4 after Chlamydia joint injection $(n=4)$. Prior $\mathrm{HgCl}_{2}$ exposure was associated with suppression of the expected rise in

\section{Figure 3}

\section{Total Serum IgE}

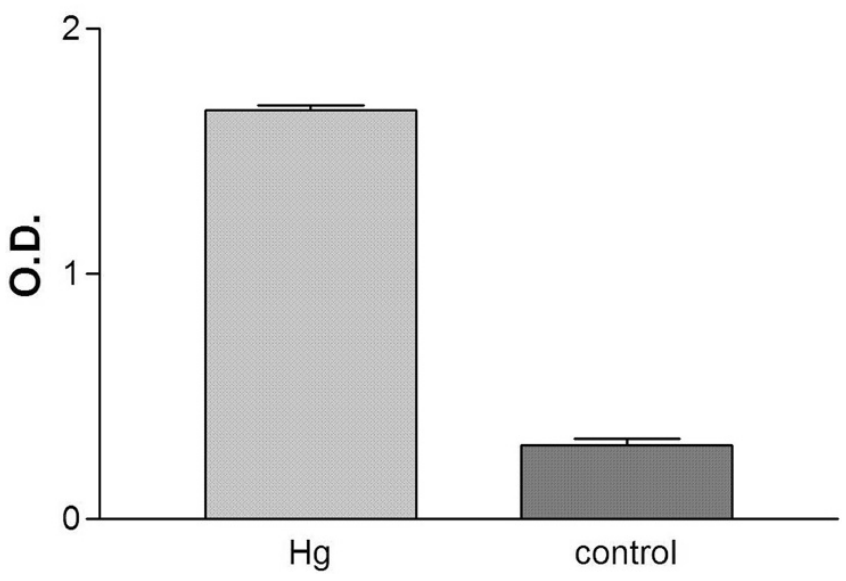

The effect of prior exposure to mercuric chloride $\left(\mathrm{HgCl}_{2}\right)$ on serum $\lg \mathrm{E}$ levels in Chlamydia-induced arthritis. The serum IgE levels are significantly increased compared with controls $(P<0.0001)(n=8$ in each group). O.D., optical density. serum IFN- $\gamma$ and TNF- $\alpha$ seen with CtIA. The differences between the $\mathrm{HgCl}_{2}$-exposed and non-exposed controls were significant for IFN- $\gamma(P=0.002)$ and TNF- $\alpha(P=0.014)$. No comparable differences were detected for IL- 4 or IL-10, but the baseline levels were low in both cases. Inflamed synovial tissues from Chlamydia-injected rats were harvested for assays for tissue cytokine profiles using the dot-blot method (Figure $5 \mathrm{~b}$ ). $\mathrm{HgCl}_{2}$ exposure was accompanied by a decrease in local cytokine production for IFN- $\gamma(P<0.005)$, TNF- $\alpha(P<$ $0.05)$, and $\mathrm{IL}-1 \quad(P<0.05)$. No significant difference was observed for synovial IL-10.

\section{Chlamydia clearance}

$\mathrm{HgCl}_{2}$-exposed rats demonstrated a relative defect in host clearance of the pathogen both locally and systemically $(n=5$ in each group). The mean level of the splenic bacterial load (measured in optical density units) for the $\mathrm{HgCl}_{2}$-exposed rats was $0.092 \pm 0.035$ in contrast with $0.009 \pm 0.003$ for the controls (Figure 6a). This clearance difference is statistically significant $(P<0.005)$. In the joint, the average Chlamydia load for the $\mathrm{HgCl}_{2}$-exposed rats was significantly higher $(0.419 \pm$ $0.264)$ than that of controls $(0.028 \pm 0.014)(P<0.05)$ (Figure $6 \mathrm{~b}$ ). Immunohistology shows more intense staining with anti-Chlamydia antibodies in the $\mathrm{HgCl}_{2}$-exposed rats (Figure $6 \mathrm{c}$ ) than in controls (Figure $6 \mathrm{~d}$ ), reflecting the relative failure of the $\mathrm{HgCl}_{2}$-exposed rat to achieve local clearance of the pathogen.

\section{Nitric oxide and vascular endothelial growth factor}

Serum NO was elevated $(3.99 \pm 0.83 \mu \mathrm{M})$ in CtIA compared with serum from naïve rats $(n=4)(2.08 \pm 0.47 \mu \mathrm{M}) . \mathrm{HgCl}_{2}$ alone had no impact on serum $\mathrm{NO}$ compared with naïve rats, but there was an additive effect of $\mathrm{Ct}$ and $\mathrm{HgCl}_{2}$ observed $(5.97 \pm 1.58 \mu \mathrm{M} ; P<0.001)$ (Figure $7 \mathrm{a})$. Serum VEGF was increased by exposure to $\mathrm{HgCl}_{2}$ alone $(56.67 \pm 20.22 \mathrm{pg} / \mathrm{mL})$ in comparison with normal rat serum $(9.21 \pm 3.3 \mathrm{pg} / \mathrm{mL})$, but $\mathrm{Ct}$ alone did not elevate serum VEGF in comparison with normal rat serum (Figure $7 \mathrm{~b}$ ). In contrast, $\mathrm{Ct}$ and $\mathrm{HgCl}_{2}$ had an additive effect on the serum VEGF $(110.56 \pm 37.37 \mathrm{pg} / \mathrm{mL} ; P$ $<0.001$ in comparison with normal rat serum). Four animals were studied in each group. The elevation in NO and VEGF was in contrast to some of the cytokine-suppressive effects of $\mathrm{HgCl}_{2}$ exposure, with serum levels of $\mathrm{NO}$ and VEGF rising more with the combined exposure than to either exposure alone. This corresponded to the most intense pathological changes in the joints of animals with dual-exposure to both $\mathrm{Ct}$ and $\mathrm{HgCl}_{2}$.

\section{Discussion}

The spondyloarthropathies (SpAs) refer to a group of diseases that share several common features: association with HLA class I genes, asymmetric oligoarthritis, axial involvement, enthesitis, and characteristic extra-articular features such as uveitis. The role of infection as a triggering factor is implicated with varying degrees of certainty amongst the SpA subcatego- 
Figure 4
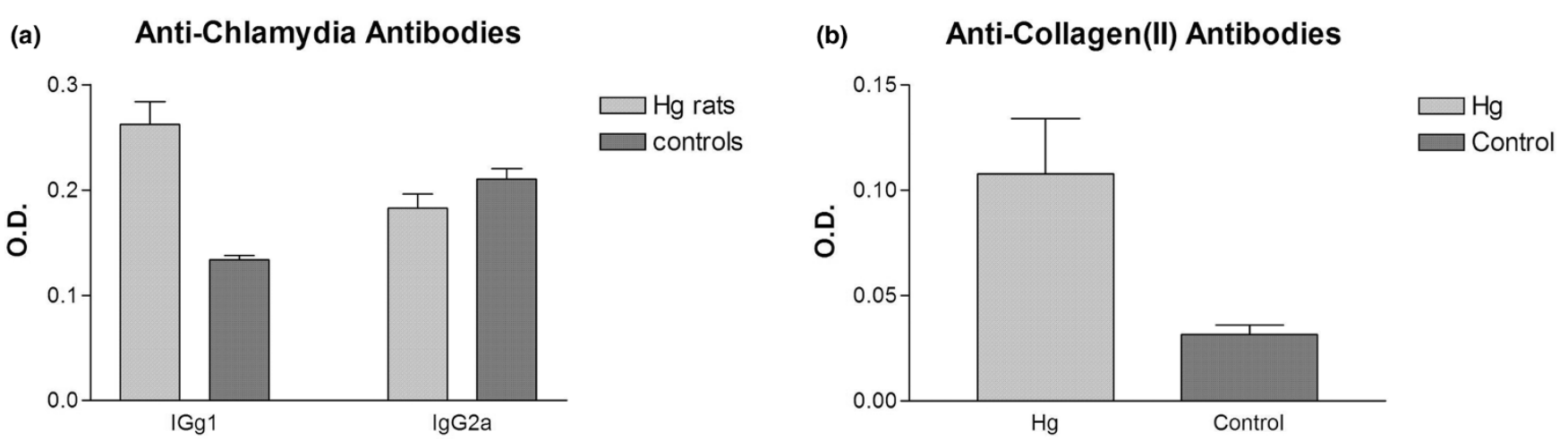

The effect of prior exposure to mercuric chloride $\left(\mathrm{HgCl}_{2}\right)$ on serum anti-Chlamydia antibodies and anti-collagen antibodies in Chlamydia-induced arthritis. (a) $\mathrm{HgCl}_{2}$-exposed rats had significantly higher serum IgG1 anti-Chlamydia antibodies than non-exposed control rats $(P<0.001)$. Control rats had slightly higher IgG2a anti-Chlamydia antibodies than the $\mathrm{HgCl}_{2}$-exposed rats $(P=0.12)$. (b) $\mathrm{HgCl}_{2}$-exposed Brown Norway (BN) rats had higher levels of IgG antibodies to rat type II collagen than controls $(P<0.01)$ ( $n=8$ in each group). O.D., optical density.

ries, with $\mathrm{ReA}$ having the most clear evidence for a microbial trigger [15]. The most direct causal evidence for microbial triggers for ReA derives from a demonstration of microbial antigens in the joint [16]. The case for intra-articular pathogens is strongest for Chlamydia, and several investigators have used polymerase chain reaction to demonstrate Chlamydia DNA or RNA in the joints of patients with post-Chlamydia $\operatorname{ReA}[17-$ 19]. There is some evidence that these organisms are metabolically altered and may have entered a quiescent phase $[20,21]$. Several studies support the notion of a viable organism present, at least transiently, in the early stages of ReA. It is speculated that this may reflect defective killing of the organism by failure either to internalize the pathogen or to effectively initiate intracellular killing. There has been particular interest in the Chlamydia heat shock proteins, notably heat shock protein 60 (hsp60), and recent studies have identified differential expression of three C. trachomatis hsp60-encoding genes that may differ in active versus persistent infections [22]. The cellular response to Chlamydia infection has been studied by microarray techniques, and 18 genes appeared to be selectively upregulated following infection with C. trachomatis [23]. Profiling Chlamydia infection of U937 monocytic cells [24] and human lung epithelial cells [25] has provided a profile of induced gene expression and, in particular, which cytokines are induced by this microbial challenge.

Analysis of cytokine profiles is a further method for studying the link between infection and ReA. In a study of 11 patients

Figure 5

(a) Serum Cytokines

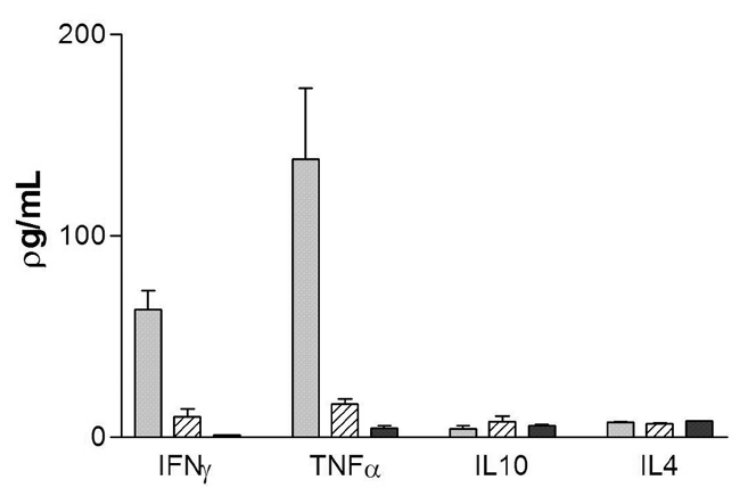

(b)

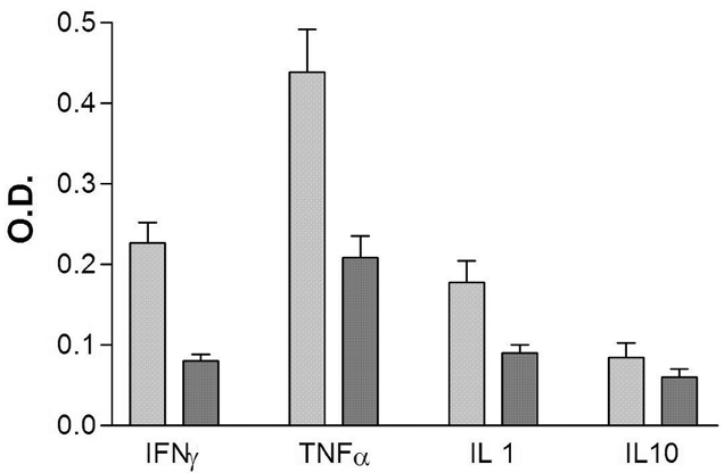

Serum and synovial cytokine profiles. (a) Serum cytokines in normal rats and in Chlamydia-induced arthritis alone or after prior exposure to mercuric chloride $\left(\mathrm{HgCl}_{2}\right)$. After the onset of Chlamydia trachomatis-induced arthritis $(\mathrm{CtIA})$, there was a significant increase in the serum levels of interferongamma (IFN- $\gamma)(P<0.005)$ and tumour necrosis factor-alpha (TNF- $\alpha)(P<0.001)$. Prior $\mathrm{HgCl}_{2}$ exposure was associated with significant suppression of IFN- $\gamma(P=0.002)$ and TNF- $\alpha(P=0.014)$ seen with CtIA. (b) Synovial cytokines in Chlamydia-induced arthritis alone or after prior exposure to $\mathrm{HgCl}_{2} . \mathrm{HgCl}_{2}$ exposure was accompanied by a decrease in local cytokine production for IFN- $\gamma(P<0.005)$, TNF- $\alpha(P<0.05)$, and interleukin (IL)$1(P<0.05)$ compared with controls. No significant difference was observed for synovial IL-10 ( $n=4$ in each group). 

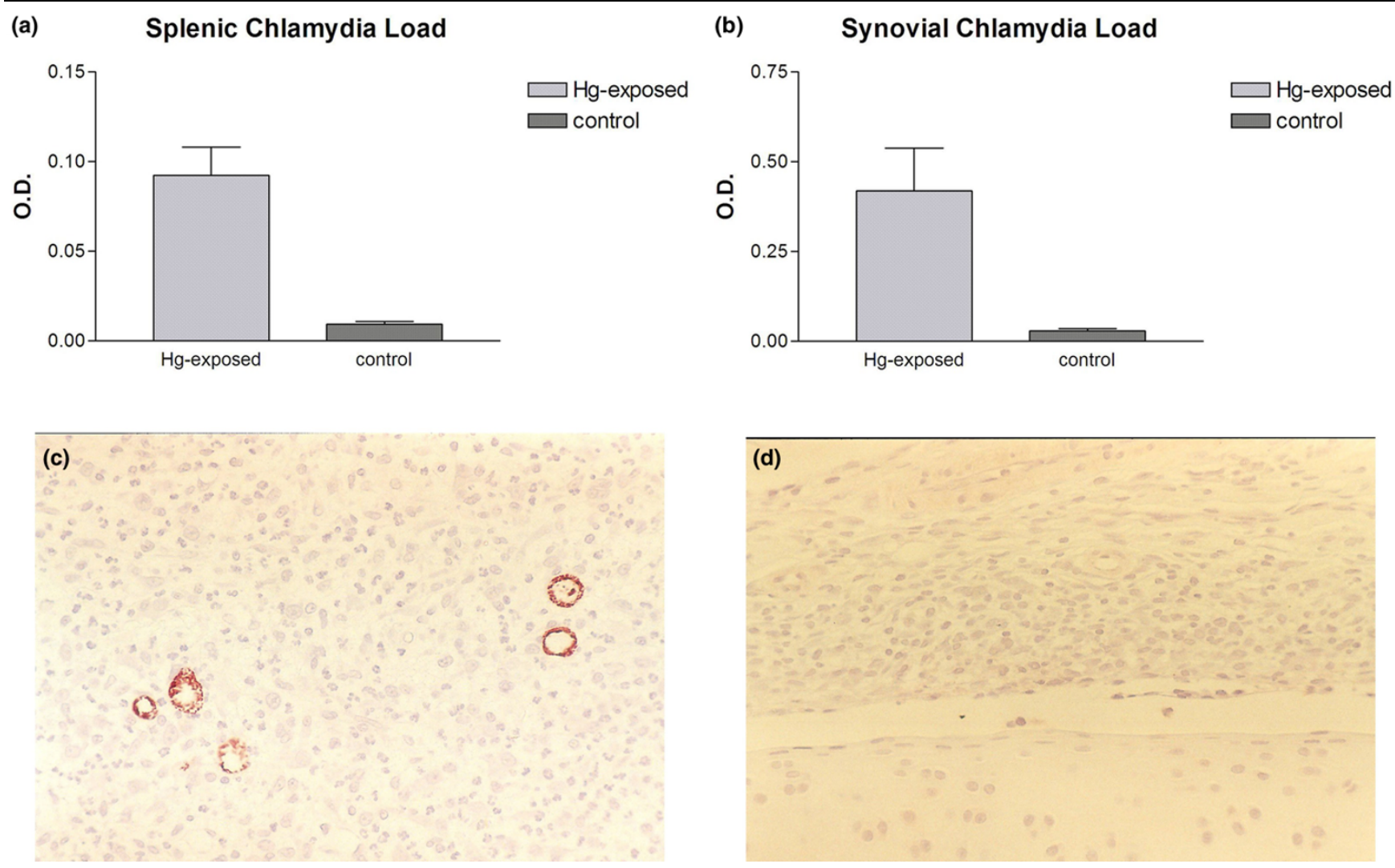

Host clearance of Chlamydia from the spleen and the joint. Tissues were harvested 5 days after the induction of Chlamydia trachomatis-induced arthritis (CtIA). (a) The mean level of the splenic bacterial load for the mercuric chloride $\left(\mathrm{HgCl}_{2}\right)$-exposed rats was higher than that of controls $(P<$ 0.005). (b) In the joint, the mean Chlamydia load for the $\mathrm{HgCl}_{2}$-exposed rats was significantly higher than that of controls $(P<0.05)$. Immunohistology shows more intense staining with anti-Chlamydia antibodies in the $\mathrm{HgCl}_{2}$-exposed rats (c) than controls (d) ( $\mathrm{n}=5$ in each group). Original magnifications $\times 200$. O.D., optical density.

with $\operatorname{ReA}$, it was observed that stimulation of SF mononuclear cells resulted in secretion of low amounts of IFN- $\gamma$ and TNF- $\alpha$ but high amounts of IL-10 [26]. IL-10 was responsible for suppression of IFN- $\gamma$ and TNF- $\alpha$ as judged by the effect of adding IL-10 or anti-IL-10 to the cells. The suppression of Th1-like cytokines is likely mediated through suppression of IL-12 synthesis. This IL-10/IL-12 balance, resulting in a predominance of Th2 cytokines, may contribute to the persistence of bacteria in the joint. In comparison with rheumatoid arthritis, SF levels of TNF- $\alpha$ in ReA are lower despite comparable levels of IL-2 receptor, again implicating a relative deficiency of protective antimicrobial cytokines in the local environment [27]. Analysis of synovial fluid cytokines has been studied in patients with Chlamydia-induced arthritis and it was found that $\mathrm{B27}^{+}$ patients had lower SF IFN- $\gamma$ levels and it was these patients who had a more chronic course [28]. This suggests that diminished IFN- $\gamma$ generation might account for the persistence of the arthritis.

Our previous studies in experimental ReA have paralleled these clinical findings. $\mathrm{BN}$ rats that are relatively resistant to
CtIA exhibit an enhanced IFN- $\gamma$ and TNF- $\alpha$ expression in the microenvironment of the joint. This is accompanied by enhanced clearance of the pathogen and a more transient and benign course of the arthritis. In the present study, we have found that this inherent resistance to ReA can be overcome by heavy metal exposure. Mercury exposure alters the cytokine profile, host clearance capability, and histopathological outcome from the resistant phenotype to the susceptible phenotype. Our findings contrast with the experience studying murine collagen-induced arthritis, in which prior exposure to $\mathrm{HgCl}_{2}$ did not influence the outcome of the arthritis, but exposure following the onset did have an aggravating effect on the arthritis [29].

If $\mathrm{HgCl}_{2}$ diminishes protective cytokines in the microenvironment of the joint, what is driving the aggressive inflammation and subsequent joint damage? Our study suggests that NO and VEGF are two important candidates. We have previously studied NO contribution to clearance of arthritogenic pathogens by synoviocytes and observed that in some instances there was an IFN- $\gamma$-mediated suppression of $\mathrm{NO}$ in such cells, 
(a)

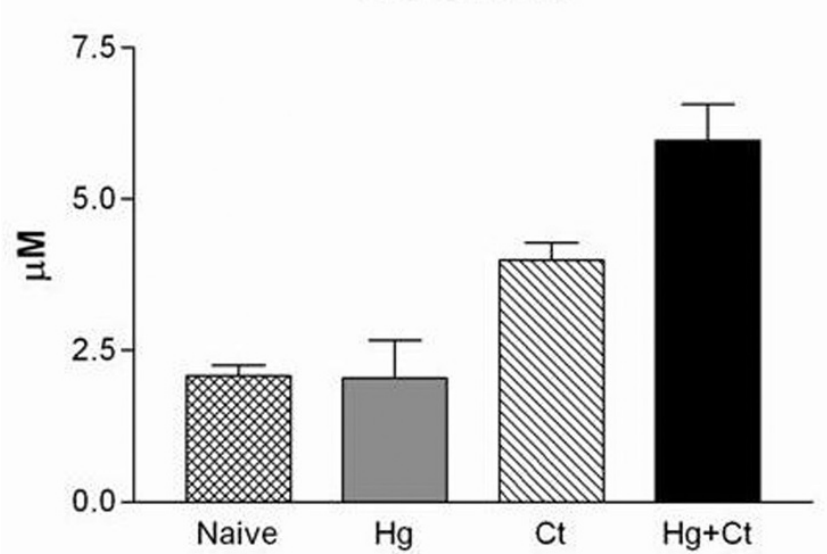

(b)

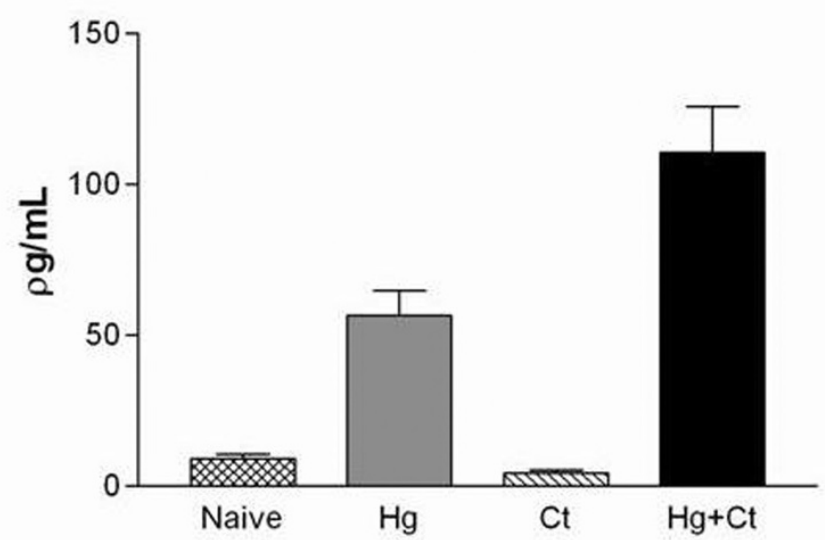

Serum nitric oxide and VEGF profiles. Serum nitric oxide (NO) levels (a) and vascular endothelial growth factor (VEGF) levels (b) with the local exposure to Chlamydia trachomatis $(\mathrm{Ct})$ or a systemic exposure to $\mathrm{HgCl}_{2}(\mathrm{Hg})$ or both $(\mathrm{Ct}+\mathrm{Hg})$ in contrast to normal rat serum. For both NO and VEGF, the increment seen with dual-exposure to $\mathrm{Ct}$ and $\mathrm{HgCl}_{2}$ was statistically greater than that seen with either $\mathrm{Ct}$ or $\mathrm{HgCl}_{2}$ alone $(\mathrm{n}=4$ in each group). $\mathrm{HgCl}_{2}$, mercuric chloride.

suggesting a dynamic interaction between these two factors [30]. This interaction may be specific to the cells under investigation since, in the case of $\mathrm{J} 774$ macrophages, IFN- $\gamma$ mediated an increase in NO production, which in turn reduced viability of C. pneumoniae in the infected cells [31]. In our in vivo model, the rise in $\mathrm{NO}$ was concurrent with an increase in chlamydial load in the host, suggesting that the increase in NO was not sufficient to contain an expanded replication profile of the organism. In this regard, it is interesting to note that, in murine cells, blockage of NO synthesis only partially rescues chlamydial growth, suggesting that there are other important IFN- $\gamma$-inducible antichlamydial mechanisms operative [32].

Prior studies on the effect of $\mathrm{Hg}$ on $\mathrm{NO}$ have yielded varying results depending on the experimental conditions. Kim and colleagues [33] found that $\mathrm{Hg}$ treatment of a macrophage cell line results in a drop in NO production upon stimulation with lipopolysaccharide. However, Huang and colleagues [34] discovered that treatment of mice with $\mathrm{Hg}$ resulted in an increase in serum NO levels. The latter results are very much in parallel with our finding of an increase of $\mathrm{NO}$ following exposure to $\mathrm{HgCl}_{2}$.

The pathological studies in our rats indicate that the exacerbation of histological severity of the arthritis was accompanied by a neovascularization process locally. It is known that VEGF plays a crucial role in angiogenesis. Spondylarthritis is characterized by enthesitis and synovitis, in which new blood vessels participate in perpetuating the inflammation. Serum analysis from SpA patients has documented that VEGF levels were significantly higher in SpA patients than in controls. In SpA patients, serum VEGF levels correlated with disease activity indices as defined by the Bath Ankylosing Spondylitis Disease
Activity Index (BASDAI), erythrocyte sedimentation rate, or Creactive protein (CRP). These results suggest that VEGF and therefore angiogenesis may play a role in SpA pathogenesis and may serve as a disease activity marker in SpAs [35]. In keeping with these findings, it has been observed that there is a significant reduction in serum VEGF levels after the infliximab treatment of $\mathrm{SpA}$ patients and that these changes correlate with similar reductions in CRP and IL-6 [36]. Direct Chlamydia-endothelial cell interactions are known to mediate induction of VEGF [37].

Mercury exists in elemental, inorganic, and organic forms. The general population is exposed primarily to mercury vapour from dental amalgam and to organic mercury from fish consumption [38]. Mercury accumulates in the food chain such that large fish such as tuna and swordfish have high concentrations of mercury in tissues [39]. Occupational exposure is primarily to mercury vapour and occurs in dentistry, mining, and the manufacture of electrical equipment. Mercury vapour is well absorbed through the respiratory tract, but absorption of elemental mercury is negligible orally whereas oral absorption of organic mercury is nearly complete [40]. There is recent evidence from studies of human peripheral mononuclear cells that low-dose exposure to mercury can polarize the immune response toward Th2 [41].

The role of mercury in rheumatic diseases has received little attention. One recent study implicated mercury exposure as a risk factor for Wegener granulomatosis [42], but the mechanism whereby mercury exposure could alter immune response and set the stage for chronic inflammatory conditions has not been resolved. Our experimental system demonstrates that genetic susceptibility can be fundamentally altered by a heavy 
metal exposure. This suggests that several environmental factors may act in concert in the pathogenesis of ReA. The immediate precipitating factor may be a bacterial infection, but this occurs in the context of other factors in the environment which influence the immune repertoire. The plasticity of the immune response, even when encoded in its basic elements by heritable factors, is highlighted in this genetic-environment interaction. As significant advances in the genetic basis of rheumatic diseases are being made, it will be a challenge to address the environmental factors with equal rigour.

\section{Conclusion}

Genetically defined cytokine production in the joint defines the severity of $\operatorname{ReA}$ by dictating the local clearance of the pathogen. This interplay can be dramatically altered by heavy metal exposure, which results in suppression of protective cytokines in the microenvironment of the joint.

\section{Competing interests}

The authors declare that they have no competing interests.

\section{Authors' contributions}

$\mathrm{RDI}$ and $\mathrm{BC}$ both contributed to the design and execution of the study, to the data analysis, and to the writing of the manuscript. Both authors read and approved the final manuscript.

\section{Acknowledgements}

The source of funding for this article was the Canadian Institutes of Health Research.

\section{References}

1. Inman RD, Chiu B: Synoviocyte-packaged Chlamydia trachomatis induces a chronic aseptic arthritis. J Clin Invest 1998, 102:1776-1782.

2. Inman RD, Chiu B: Early cytokine profiles in the joint define pathogen clearance and severity of arthritis in Chlamydiainduced arthritis in rats. Arthritis Rheum 2006, 54:499-507.

3. Fournié GJ, Cautain B, Xystrakis E, Damoiseaux L, Mas M, Lagrange D, Bernard I, Subra JF, Pelletier L, Druet P, Saoudi A: Cellular and genetic factors involved in the difference between Brown Norway and Lewis rats to develop respectively type-2 and type-1 immune-mediated diseases. Immunol Rev 2001, 184:145-160.

4. Fournie GJ, Saoudi A, Druet P, Pelletier L: Th2-type immunopathological manifestations induced by mercury chloride or gold salts in the rat: signal transduction pathways, cellular mechanisms and genetic control. Autoimmun Rev 2002, 1:205-212.

5. Gorrie MJ, Qasim FJ, Whittle CJ, Gillespie KM, Szeto CC, Nicoletti F, Bolton EM, Bradley JA, Mathieson PW: Exogenous type-1 cytokine modulate mercury-induced hyper-IgE in the rat. Clin Exp Immunol 2000, 121:17-22.

6. Kiely PDW, Thiru S, Oliveira DBG: Inflammatory polyarthritis induced by mercuric chloride in the Brown Norway rat. $L a b$ Invest 1995, 73:284-293.

7. Qasim FJ, Thiru S, Mathieson PW, Oliveira DB: The time course and characterization of mercuric chloride-induced immunopathology in the Brown Norway rat. J Autoimmun 1995, 8:193-208

8. Kosuda LL, Greiner DL, Bigazzi PE: Mercury induced renal autoimmunity in BN to Lew.1N chimeric rats. Cell Immunol 1994, 155:77-94.

9. White KL, David DW, Butterworth LF, Klykken PC: Assessment of autoimmunity-inducing potential using the brown Norway rat challenge model. Toxicol Lett 2000, 12-113:443-451.
10. Prouvost-Danon A, Abadie A, Sapin C, Bazin H, Druet P: Induction of $\lg E$ synthesis and potentiation of anti-ovalbumin $\operatorname{lgE}$ antibody response by $\mathrm{HgCl} 2$ in the rat. J Immunol 1981, 126:699-792.

11. Prigent $P$, Saoudi $A$, Pannetier $C$, Graber $P$, Bonnefoy JY, Druet $P$, Hirsch F: Mercuric chloride, a chemical responsible for $T$ helper cell (Th)2-mediated autoimmunity in brown Norway rats, directly triggers $\mathrm{T}$ cells to produce interleukin-4. J Clin Invest 1995, 96:1484-1489.

12. Gillespie KM, Saoudi A, Kuhn J, Whittle CJ, Druet $P$, Bellon B, Mathieson PW: Th1/Th2 cytokine gene expression after mercuric chloride in susceptible and resistant rat strains. Eur J Immunol 1996, 26:2388-2392.

13. Roos A, Claessen N, Weening JJ, Aten J: Enhanced T lymphocyte expression of LFA-1, ICAM-1, and the TNF receptor family member $\mathrm{OX} 40$ in $\mathrm{HgCl}_{2}$-induced systemic autoimmunity. Scand J Immunol 1996, 43:507-518.

14. Roos A, Claessen N, Schilder-Tol EJ, Weening JJ, Aten J: Differential expression of T-cell adhesion molecules and LFA-1 dependent intercellular adhesion in the $\mathrm{HgCl}$-induced autoimmunity and immune suppression. Scand J Immunol 1998, 48:389-396.

15. Inman RD, Perl A: Infectious agents in chronic rheumatic diseases. In Arthritis and Allied Conditions: A Textbook of Rheumatology 15th edition. Edited by: Koopman WJ. Philadelphia: Lippincott Williams \& Wilkins; 2005:647-678.

16. Hannu H, Inman RD, Granfors K, Leirisalo-Repo M: Reactive arthritis or postinfectious arthritis. Best Pract Res Clin Rheum 2006, 20:419-433.

17. Kuipers JG, Jurgen-Saathoff $B$, Bialowons $A$, Wollenhaupt J, Kohler $\mathrm{L}$, Zeidler H: Detection of Chlamydia trachomatis in peripheral blood lymphocytes of reactive arthritis patients by polymerase chain reaction. Arthritis Rheum 1998, 41:1894-1895.

18. Branigan PJ, Gerard HC, Hudson AP, Schumacher HR, Pando J: Comparison of synovial tissue and synovial fluid as the source of nucleic acids for the detection of Chlamydia trachomatis by polymerase chain reaction. Arthritis Rheum 1996, 39:1740-1746.

19. Bas S, Griffais R, Kvien TK, Glennas A, Melby K, Vischer TL: Amplification of plasmid and chromosome Chlamydia DNA in synovial fluids of patients with reactive arthritis an undifferentiated seronegative spondyloarthropathies. Arthritis Rheum 1995, 38:1005-1013

20. Gerard HC, Branigan PJ, Schumacher HR, Hudson AP: Synovial Chlamydia trachomatis in patients with reactive arthritis/ Reiter's syndrome are viable but show aberrant gene expression. J Rheumatol 1998, 25:734-742.

21. Nanagara R, Li F, Beutler AM, Hudson A, Schumacher HR: Alteration of Chlamydia trachomatis biological behavior in synovial membranes: suppression of surface antigen production in reactive arthritis. Arthritis Rheum 1995, 38:1410-1417.

22. Gerard HC, Whittum-Hudson JA, Schumacher HR, Hudson AP: Differential expression of three Chlamydia trachomatis hsp60encoding genes in active vs persistent infections. Microb Pathog 2004, 36:35-39.

23. Hess S, Rheinheimer C, Tidow F, Bartling G, Kaps C, Lauber J, Buer J, Klos A: The reprogrammed host: Chlamydia trachomatis-induced upregulation of glycoprotein 130 cytokines, transcription factors and antiapoptotic genes. Arthritis Rheum 2001, 44:2392-2401.

24. Virok D, Loboda A, Kari L, Nebozhyn M, Chang C, Nichols C Endresz V, Gonczol E, Berencsi K, Showe MK, Showe LC: Infection of U937 monocytic cells with Chlamydia pneumoniae induces extensive changes in host cell gene expression. $J$ Infect Dis 2003, 188:1310-1321.

25. Yang J, Hooper WC, Phillips DJ, Tondella ML, Talkington DF: Induction of proinflammatory cytokines in human lung epithelial cells during Chalmydia pneumoniae infection. Infect Immun 2003, 71:614-620.

26. Yin Z, Braun J, Neure L, Wu P, Liu L, Eggens U, Sieper J: Crucial role of interleukin-10/interleukin-12 balance in the regulation of the type $\mathbf{2} \mathrm{T}$ helper cytokine response in reactive arthritis. Arthritis Rheum 1997, 40:1788-1797.

27. Steiner G, Studnicka-Benke A, Witzmann G, Hofler E, Smolen J: Soluble receptors for tumor necrosis factor and interleukin-2 in serum and synovial fluid of patients with rheumatoid arthri- 
tis, reactive arthritis, and osteoarthritis. J Rheumatol 1995, 22:406-412.

28. Bas S, Kvien TK, Buchs N, Fulpius T, Gabay C: Lower level of synovial fluid IFN- $\gamma$ in HLA-B27-positive than in HLA-B27-negative patients with Chlamdyia trachomatis reactive arthritis. Rheumatology (Oxford) 2003, 42:461-467.

29. Hansson $M$, Djerbi $M$, Rabbani $H$, Mellstedt $H$, Gharibdoost $F$, Hassan M, Depierre JW, Abedi-Valugerdi M: Exposure to mercuric chloride during the induction phase and after the onset of collagen-induced arthritis enhances immune/autoimmune responses and exacerbates the disease in DBA/1 mice. Immunology 2005, 114:428-437.

30. Inman RD, Payne U: Determinants of synoviocyte clearance of arthritogenic bacteria. J Rheumato/ 2003, 30:1291-1297.

31. Carratelli CR, Rizzo A, Paolillo R, Catania MR, Catalanotti P, Rossano F: Effect of nitric oxide on the growth of Chlamydophila pneumoniae. Can J Microbio/ 2005, 51:941-947.

32. Roshick C, Wood H, Caldwell HD, McClarty G: Comparison of gamma interferon-mediated antichlamydial defense mechanisms in human and mouse cells. Infect Immun 2006, 74:225-238.

33. Kim SH, Johnson VJ, Sharma RP: Mercury inhibits nitric oxide production but activates proinflammatory cytokine expression inmurine macrophage: differential modulation of NF- $\mathrm{BB}$ and p38 MAPK signaling pathways. Nitric Oxide 2002, 7:67-74.

34. Huang CF, Liu SH, Lin-Shiau SY: Neurotoxicological effects of cinnabar (HgS) in mice. Toxicol Appl Pharmacol 2007, 224:192-201.

35. Drouart $M$, Saas $P$, Billot $M$, Cedoz JP, Tiberghien $P$, Wendling $D$, Toussirot $E$ : High serum vascular endothelial growth factor correlates with disease activity of spondylarthropathies. Clin Exp Immunol 2003, 132:158-162.

36. Visvanathan S, Wagner C, Marini JC, Baker D, Gathany T, Han J, van der Heijde D, Braun J: Inflammatory biomarkers, disease activity, and spinal disease measures in patients with ankylosing spondylitis after treatment with infliximab. Ann Rheum Dis 2008, 65:511-517.

37. Carratelli CR, Paolillo R, Rizzo A: Chlamydia pneumoniae stimulates the proliferation of HUVEC through the induction of VEGF by THP-1. Int Immunopharmacol 2006, 7:287-294.

38. Brodkin E, Copes R, Mattman A, Kennedy J, Kling R, Yassi A: Lead and mercury exposures: interpretation and action. CMAJ 2007, 176:59-63.

39. Bureau of Chemical Safety, Food Directorate, Health Products and Food Branch (Government of Canada): Human Health Risk Assessment of Mercury in Fish and Health Benefits of Fish Consumption 2007:1-70 [http://www.hc-sc.gc.ca/fn-an/pubs/mercur/ merc fish poisson-eng.php]. Ottawa, ON: Health Canada

40. Mozaffarian D, Rimm EB: Fish intake, contaminants, and human health: evaluating the risks and the benefits. JAMA 2006, 296:1885-1899.

41. Hemdan NY, Lehmann I, Wichmann G, Lehmann J, Emmrich F, Sack U: Immunomodulation by mercuric chloride in vitro: application of different cell activation pathways. Clin Exp Immuno1 2007, 148:325-337.

42. Albert D, Clarkin C, Komoroski J, Brensinger CM, Berlin JA: Wegener's granulomatosis: possible role of environmental agents in its pathogenesis. Arthritis Rheum 2004, 51:656-664. 